\title{
Pengklonaan Plasmid Rekombinan gp125-gp36 Human Immunodeficiency Virus tipe 2 (HIV-2) untuk Pengembangan Sistem Diagnostik HIV-2
}

\author{
Fathurrohim $^{1}$, Silvia Tri Widyaningtyas ${ }^{2}$, Budiman Bela ${ }^{2,3^{*}}$ \\ ${ }^{1}$ Program Magister Ilmu Biomedik, Fakultas Kedokteran, Universitas Indonesia \\ ${ }^{2}$ Pusat Riset Virologi dan Kanker Patobiologi, Fakultas Kedokteran, Universitas Indonesia, \\ ${ }^{3}$ Departemen Mikrobiologi, Fakultas Kedokteran, Universitas Indonesia, \\ *E-mail: budiman.bela@yahoo.com, budiman.bela@ui.ac.id
}

\begin{abstract}
From 36.9 million people infected by the Human Immunodeficiency Virus (HIV) at the end of 2018 in the whole world, 1-2 million are infected by HIV-2. Accurately diagnostic is required to ensure whether an individual has been infected HIV-1, HIV-2, or HIV-1 and HIV-2 co-infection. HIV-2 diagnostic error using rapid diagnostic tests (RDT) frequently occurs. Misdiagnostic of HIV-2 infection may cause treatment failure which leads to the development of Acquired Immune Deficiency Syndrome (AIDS). In this study, expression plasmid pQE80Lgp125-gp 36 HIV-2 that can produce recombinant antigen gp125-gp36 HIV-2 was successfully constructed and verified properly. The antigen is based on multiepitope, immunodominant and sustainable properties obtained by bioinformatics study. Plasmid pQE80L-gp125-gp36 HIV-2 may be used to produce recombinant antigens that benefit to detect anti-HIV-2 antibodies in an individual.
\end{abstract}

Keywords: Antigen, Diagnostic, HIV-2, Cloning; Recombinant

\begin{abstract}
Abstrak
Dari 36,9 juta individu yang terinfeksi oleh Human Immunodeficiency Virus (HIV) pada akhir tahun 2018 di seluruh dunia, terdapat sekitar $1-2$ juta individu yang terinfeksi dengan HIV-2. Diagnostik yang akurat diperlukan untuk menentukan apakah suatu individu telah terinfeksi HIV-1, HIV-2 atau koinfeksi HIV-1 dan HIV-2. Kesalahan diagnostik HIV-2 menggunakan rapid diagnostic tests (RDT) sering sekali terjadi. Misdiagnosis infeksi HIV-2 dapat menyebabkan kegagalan pengobatan yang berujung pada perkembangan Acquired Immune Deficiency Syndrome (AIDS). Pada penelitian ini plasmid pQE80L-gp125-gp36 HIV-2 pengekspresi antigen rekombinan gp125-gp36 HIV-2 telah berhasil dikonstruksi dan terverifikasi dengan baik. Antigen tersebut berbasis multiepitop, immunodominan dan bersifat lestari yang didapatkan dari studi bioinformatik. Plasmid pQE80L-gp125-gp36 HIV-2 dapat digunakan untuk memproduksi antigen rekombinan yang dapat dimanfaatkan untuk mendeteksi antibodi anti HIV-2 pada suatu individu.
\end{abstract}

Kata kunci: Antigen; Diagnostik; HIV-2; Kloning; Rekombinan

\section{Pendahuluan}

Infeksi Human Immunodeficiency Virus tipe 2 (HIV-2) merupakan salah satu penyebab penyakit yang banyak terjadi di sejumlah wilayah di dunia. ${ }^{1,2}$ Dari 36,9 juta orang yang terinfeksi oleh HIV pada akhir tahun 2018 di seluruh dunia, terdapat sekitar satu sampai dua juta yang terinfeksi dengan HIV-2. ${ }^{3}$ Di era globalisasi ini tidak menutup kemungkinan infeksi HIV-2 dapat menjadi pandemi global seperti Human Immunodeficiency Virus tipe 1 (HIV-1) mengingat cara penularannya yang sama seperti HIV $-1{ }^{2}$

Dalam suatu tes diagnostik HIV, diperlukan pengujian yang dapat menentukan apakah suatu individu telah terinfeksi HIV-1, HIV-2 atau koinfeksi 
HIV-1 dan HIV-2. Penentuan tersebut sangat penting mengingat adanya perbedaan dalam hal perkembangan penyakit serta pemilihan antiretroviral treatment (ART) yang akan diberikan. Misdiagnosis infeksi HIV-2 pada pasien yang dianggap sebagai individu terinfeksi HIV-1 atau pada individu yang koinfeksi HIV-1 dan HIV-2 dapat menyebabkan kegagalan pengobatan yang berujung pada perkembangan Acquired Immune Deficiency Syndrome (AIDS). ${ }^{4}$

Uji skrining infeksi HIV-2 dapat dilakukan dengan rapid diagnostic tests (RDT). Uji ini dapat membedakan antara infeksi HIV-1 dan HIV-2. ${ }^{5}$ Pada saat ini, RDT yang ada untuk mendeteksi infeksi HIV-2 hanya menggunakan peptida spesifik dari gp36. ${ }^{5,6}$ Kesalahan diagnostik HIV-2 menggunakan RDT sering sekali terjadi. Dari 312 individu yang diklasifikasikan terinfeksi HIV-2, terdapat $5,1 \%$ yang direklasifikasi sebagai individu terinfeksi HIV-1. Kemudian dari 235 individu yang diklasifikasikan koinfeksi HIV-1 dan HIV-2, terdapat 43,8\% yang direklasifikasi sebagai individu monoinfeksi HIV-1. ${ }^{7}$

Menurut penelitian yang dilakukan oleh Leligdowicz dkk, daerah yang paling imunodominan pada HIV-2 adalah protein Gag dan yang kedua adalah protein Env (gp125 dan gp36). ${ }^{8}$ Akan tetapi, pada protein Gag banyak terjadi reaksi silang dengan HIV $-1 .{ }^{8}$ Pengembangan antigen rekombinan HIV-2 yang menggunakan beberapa peptida spesifik dari protein Env (target protein: 28,27 $\mathrm{kDa}$ ) diperlukan untuk mengatasi permasalahan tersebut. Penelitian ini bertujuan untuk membuat klon plasmid pengekspresi antigen rekombinan spesifik gp125-gp36 HIV-2 yang berbasis multiepitop, immunodominan dan bersifat lestari.

\section{Metode}

\section{Penyiapan DNA sisipan dan vektor}

Gen penyandi antigen rekombinan gp125-gp36 HIV-2 (741 pb) dibuat secara sintetik (Macrogen) dalam vektor plasmid pUC57 untuk selanjutnya disubklona ke vektor ekspresi pQE80L (Qiagen). Gen tersebut didapatkan dari transkripsi balik hasil studi literatur dan bioinformatik dengan memprediksi epitop linear sel B menggunakan immune epitope database (IEDB) (https://www.iedb.org), serta piranti lunak Mega7 dan BioEdit untuk menganalisis epitop yang bersifat lestari. ${ }^{9}$ Strategi pengklonaan dapat dilihat pada Gambar 1.

Plasmid pQE80L dan pUC57-gp125gp36 HIV-2 yang berada pada E. coli Top10 (Invitrogen) ditumbuhkan pada media Luria-Bertani (LB) (500 ml) dengan ampisilin $(100 \mu \mathrm{g} / \mathrm{ml})$ untuk diisolasi plasmid sesuai dengan metode Hispeed Maxi Kit (Qiagen). Penyiapan vektor ekspresi dan DNA sisipan dilakukan dengan merestriksi plasmid menggunakan enzim BamHI (New England Biolabs NEB) dan HindIII (NEB). Total masingmasing plasmid pada proses ini adalah 10 $\mu \mathrm{g}$. Restriksi pertama dilakukan dengan enzim BamHI (NEB) kemudian dilanjutkan dengan proses purifikasi menggunakan Qiaex II (Qiagen). Restriksi kedua dilakukan dengan enzim HindIII (NEB). Untuk mencegah vektor ekspresi pQE80L autoligasi, dilakukan reaksi calf intestinal alkaline phosphatase (CIAP) menggunakan enzim FastAp (Fermentas). DNA vektor dan DNA sisipan yang telah direstriksi kemudian dielektroforesis gel low melting agarose (LMA) dan dilanjutkan ke tahapan desalting sesuai prosedur Qiaex II (Qiagen). Hasil purifikasi dielektroforesis gel agarose $0,8 \%$ (b/v) 100 volt, 30 menit.

\section{Ligasi}

Ligasi DNA vektor dan DNA sisipan dilakukan dengan perbandingan rasio molar $1: 3$ menggunakan enzim T4 ligase (NEB). Campuran diinkubasikan menggunakan inkubator $16^{\circ} \mathrm{C}$ selama 16 jam. 


\section{Transformasi}

Plasmid hasil ligasi ditransformasikan ke sel E. coli Top10 (Invitrogen) kompeten menggunakan metode heat shock. Pembuatan sel kompeten dilakukan secara kimiawi menggunakan $100 \mathrm{mM} \mathrm{MgCl}_{2}$ dan 100 $\mathrm{mM} \mathrm{CaCl} 2$. Sebanyak $5 \mu \mathrm{l}$ plasmid hasil ligasi ditambahkan pada E. coli Top10 kompeten. Campuran diinkubasi di es selama 1 jam, kemudian diinkubasi menggunakan penangas air $38^{\circ} \mathrm{C}$ selama 90 detik dan diinkuasi kembali di es selama 60 detik. Medium Super Optimal broth with Catabolites (SOC) (Thermo scientific) ditambahkan sebanyak $200 \mu$ kemudian diinkubasi pada inkubator shaker $150 \mathrm{rpm}$ dengan suhu $37^{\circ} \mathrm{C}$, selama 1 jam. Sebanyak $50 \mu$ campuran disebar pada LB agar dengan ampisilin $(100 \mu \mathrm{g} / \mathrm{ml})$ dan diinkubasi pada inkubator dengan suhu $37^{\circ} \mathrm{C}$, selama 16 jam.

\section{Verifikasi}

Koloni yang tumbuh dari hasil transformasi diverifikasi menggunakan PCR koloni, analisis restriksi, dan sekuensing. Primer yang digunakan untuk PCR koloni adalah pQE forward dan $\mathrm{pQE}$ reverse. Hasil positif akan ditunjukkan dengan penambahan panjang nukleotida sebanyak $250 \mathrm{pb}$. Koloni E. coli yang dianalisis PCR dibuat juga replikanya pada LB agar yang mengandung ampisilin. Hasil PCR koloni dielektroforesis gel agarose $0,8 \%$ (b/v) 100 volt, 30 menit.

Koloni yang menunjukkan hasil positif diisolasi plasmidnya menggunakan kit QIAprep Spin Miniprep (Qiagen) kemudian diverifikasi lebih lanjut menggunakan analisis enzim restriksi BamHI (NBE) dan HindIII (NBE). Analisis enzim restriksi juga dilakukan menggunakan enzim yang memotong di daerah sisipan yaitu enzim PstI (NBE). Hasil restriksi dielektroforesis gel agarose 0,8\% (b/v) 100 volt, 30 menit. Hasil positif dari PCR koloni dan analisis enzim restriksi selanjutnya dilakukan sekuensing. Analisis hasil sekuensing dilakukan menggunakan software BioEdit versi 7.2.6 dan Mega7 versi 7.0.26.

\section{Hasil}

Pengklonaan gen sintetik gp125gp36 HIV-2 diawali dengan penyiapan vektor ekspresi (plasmid pQE80L) dan DNA sisipan penyandi antigen rekombinan gp125-gp36 HIV-2 dengan merestriksi plasmid pQE80L dan pUC57-gp125-gp36 HIV-2 menggunakan enzim BamHI dan HindIII. Hasil restriksi dapat dilihat pada Gambar 2.

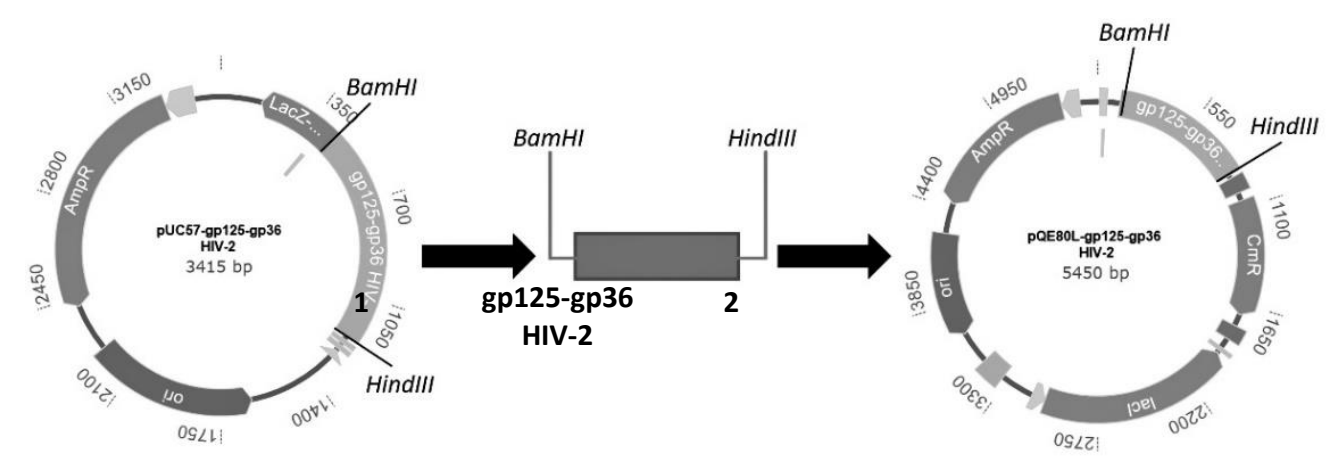

Gambar 1. Strategi pengklonaan gen sintetik gp125-gp36 HIV-2. Ket: 1: Pemotongan dengan enzim restriksi BamHI dan HindIII. 2: sub-klon ke plasmid pQE80L.

Vektor plasmid pQE80L mempuyai panjang $4751 \mathrm{pb}$. Pemotongan dengan enzim restriksi BamHI dan HindIII menghasilkan DNA dengan panjang 4709 pb dan $42 \mathrm{pb}$. Untuk DNA dengan panjang $42 \mathrm{pb}$ tidak dapat terlihat pada gel agarose. Adapun plasmid pUC57-gp125-gp36 HIV2 mempunyai panjang $3415 \mathrm{pb}$, 
Pemotongan dengan enzim restriksi BamHI dan HindIII menghasilkan DNA dengan panjang 2674 pb (pUC57) dan 741 $\mathrm{pb}$ (DNA penyandi antigen spesifik gp125gp36 HIV-2).

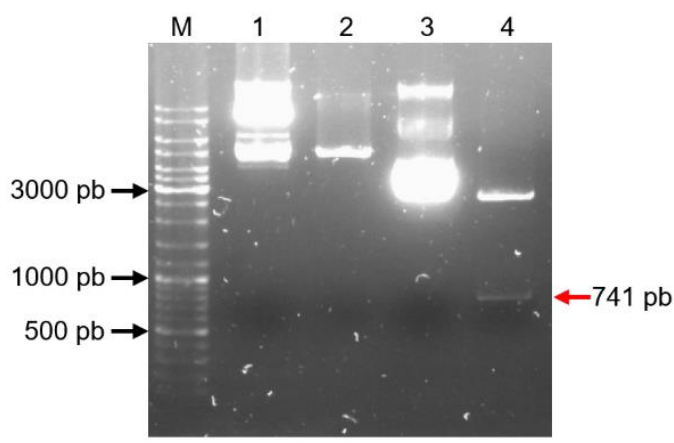

Gambar 2. Elektroforesis gel agarose plasmid pQE80L dan pUC57-gp125-gp36 HIV-2. M: Marker. Lajur 1 dan 3: Plasmid pQE80L (4751 pb) dan pUC57-gp125-gp36 HIV-2 (3415 pb) yang tidak dipotong enzim restriksi. Lajur 2 dan 4: Plasmid pQE80L (4709 pb) dan pUC57-gp125gp36 HIV-2 (2674 pb dan $741 \mathrm{pb})$ yang dipotong dengan enzim restriksi BamHI dan HindIII.

DNA vektor dan sisipan kemudian dipurifikasi menggunakan LMA. Hasilnya diperoleh konsentrasi DNA vektor (pQE80L) 10,2 ng/ $\mu \mathrm{l}$, dan DNA sisipan (gen sintetik penyandi antigen rekombinan gp125-gp36 HIV-2) 15,2 ng/ $\mu$ l. Elektroforesis gel agarose hasil purifikasi LMA dapat dilihat pada Gambar 3. Dari hasil tersebut terkonfirmasi bahwa DNA vektor dan DNA sisipan mempunyai ukuran yang sesuai yaitu: 4709 pb dan 741 $\mathrm{pb}$.

Ligasi antara DNA vektor dan DNA sisipan menghasilkan plasmid rekombinan pQE80L-gp125-gp36 HIV-2 dengan panjang $5450 \mathrm{pb}$. Jumlah koloni yang tumbuh dari hasil transfomasi plasmid rekombinan dapat dilihat pada Tabel 1 .

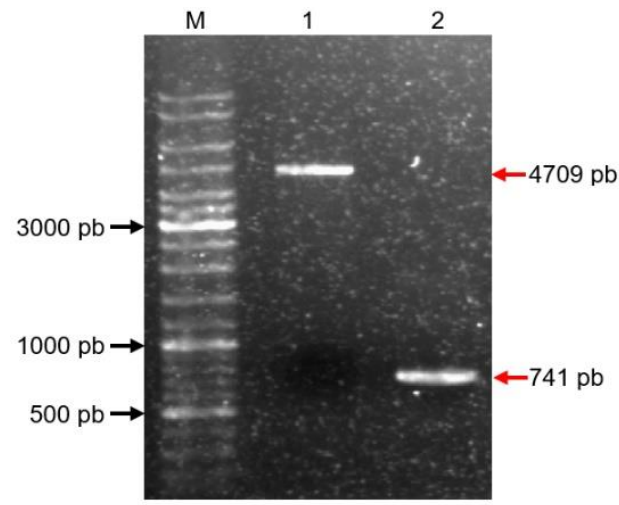

Gambar 3. Elektroforesis gel agarose hasil purifikasi DNA sisipan (DNA penyandi antigen rekombinan gp125-gp36 HIV-2) dan DNA vektor (plasmid pQE80L). M: Marker. Lajur 1: DNA vektor pQE80L (4709). Lajur 2: DNA sisipan penyandi antigen rekombinan gp125-gp36 HIV-2 (741 pb).

Tabel 1. Jumlah koloni $E$. coli Top10 hasil transformasi.

\begin{tabular}{lc}
\hline \multicolumn{1}{c}{ DNA yang ditransformasi } & $\begin{array}{c}\text { Jumlah } \\
\text { koloni }\end{array}$ \\
\hline pQE80L-gp125-gp36 HIV-2 (plasmid \\
hasil ligasi DNA sisipan gp125-gp36 & 1168 \\
HIV-2 dengan vektor pQE80L & \\
pQE80L hasil restriksi tanpa DNA & 73 \\
sisipan (kontrol ligasi) & \\
pQE80L wild type (Kontrol positif \\
transformasi) \\
$\begin{array}{l}\text { Tanpa plasmid (kontrol negatif } \\
\text { transformasi) }\end{array}$
\end{tabular}

Keterangan: (tidak bisa dihitung)

Verifikasi plasmid rekombinan hasil ligasi kemudian dilakukan menggunakan tiga metode yaitu PCR koloni, analisis restriksi dan sekuensing. Dari sepuluh koloni yang dipilih secara acak, terdapat 1 koloni yang positif mengandung gen sisipan penyandi antigen rekombinan gp125-gp36 HIV-2. Hasil positif PCR koloni dapat dilihat pada Gambar 4 yang ditunjukkan oleh pita berukuran $991 \mathrm{pb}$. Panjang pita DNA tersebut berasal dari 741 pb DNA sisipan penyandi antigen rekombinan gp125-gp36 HIV-2 dan 250 pb dari DNA plasmid. 


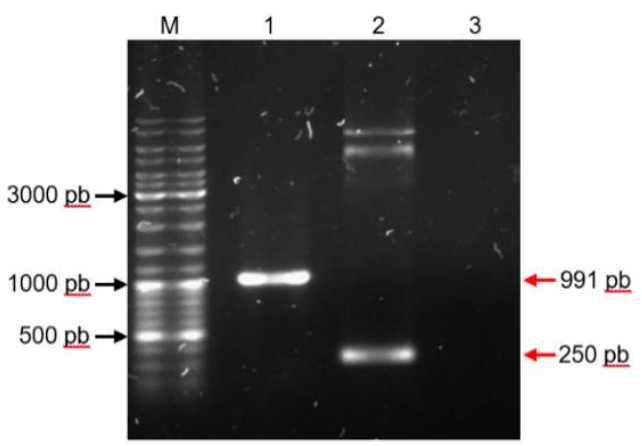

Gambar 4. Elektroforesis gel agarose hasil PCR koloni. M: Marker. Lajur 1: Koloni E. coli Top10pQE80L-gp125-gp36 HIV-2 (hasil positif $991 \mathrm{pb}$ ). Lajur 2: Kontrol positif PCR koloni (plasmid pQE80L wild type) (250 pb). Lajur 3: Kontrol negatif PCR koloni (tanpa template DNA).

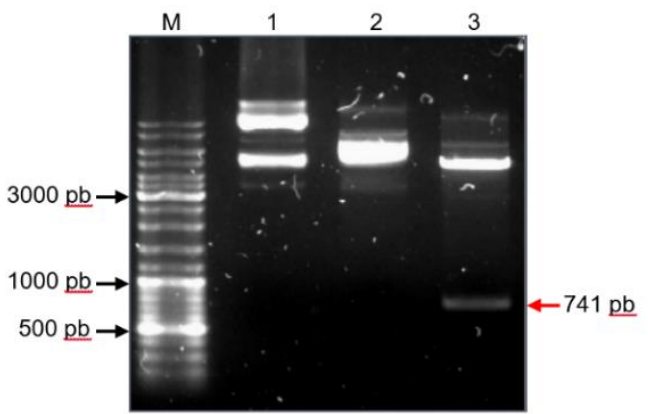

(A)

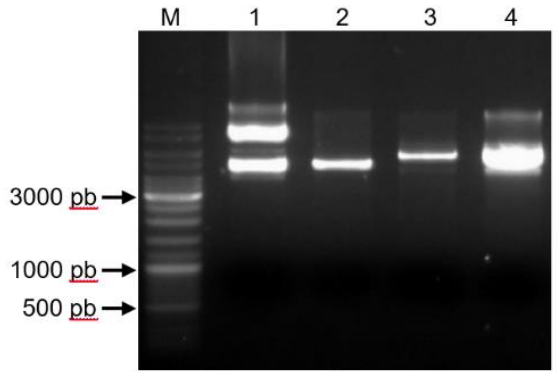

(B)

Gambar 5. Elektroforesis gel agarose hasil analisis enzim restriksi. M: Marker. (A). Analisis enzim restriksi menggunakan BamHI dan HindIII. Lajur 1 dan 2: Plasmid pQE80L wild type (4751 pb) dan pQE80L-gp125-gp36 HIV-2 yang tidak dipotong enzim restriksi $(5450 \mathrm{pb})$. Lajur 3: Plasmid rekombinan pQE80L-gp125-gp36 HIV-2 yang dipotong dengan enzim restriksi BamHI dan HindIII (4709 pb dan 741 pb). (B). Analisis enzim restriksi menggunakan PstI. Lajur 1 dan 4: Plasmid pQE80L wild type (4751 pb) dan pQE80L-gp125gp36 HIV-2 yang tidak dipotong enzim restriksi (5450 pb). Lajur 2 dan 3: Plasmid pQE80L wild type (4751 pb) dan pQE80L-gp125-gp36 HIV-2 yang dipotong dengan enzim restriksi PstI (5450 $\mathrm{pb).}$

Analisis restriksi dilakukan untuk koloni yang positif berdasarkan PCR koloni. Enzim restriksi yang digunakan adalah BamHI dan HindIII. Hasil analisis dapat dilihat pada Gambar 5. Plasmid rekombinan pQE80L-gp125-gp36 HIV-2 mempunyai panjang $5450 \mathrm{pb}$. Pemotongan dengan enzim restriksi BamHI dan HindIII menghasilkan DNA dengan panjang 4709 pb (pQE80L) dan $741 \mathrm{pb}$ (DNA penyandi antigen rekombinan gp125-gp36 HIV-2). Analisis enzim restriksi juga dilakukan menggunakan enzim restriksi yang memotong di bagian DNA sisipan (PstI). Pemotongan dengan enzim restriksi PstI menghasilkan DNA linier dengan panjang 5450.

Koloni yang terverifikasi dengan dua metode tersebut kemudian dilakukan sekuensing (hasil tidak dilampirkan karena dalam proses pengajuan paten). Berdasarkan hasil analisis sekuensing, susunan DNA penyandi antigen rekombingan gp125-gp36 HIV-2 sesuai dengan rancangan dan tidak ada mutasi yang terjadi.

\section{Pembahasan}

Diagnostik infeksi HIV-2 perlu dibedakan dari infeksi HIV-1 karena adanya perbedaan dalam hal perkembangan penyakit serta pengobatan yang akan diberikan. ${ }^{2}$ Kesalahan diagnostik HIV-2 menggunakan RDT sering sekali terjadi. ${ }^{7}$ Hal tersebut disebabkan karena persamaan homologi sekuens asam amino antara HIV-1 dan HIV-2 yang cukup besar dan besarnya variasi antar subtipe maupun di dalam satu subtipe HIV-2. ${ }^{1}$ Antigen rekombinan HIV2 yang dimanfaatkan untuk deteksi antibodi anti-HIV-2 hanya menggunakan peptida spesifik gp36., ${ }^{5,6}$ Beberapa asam amino dari peptida spesifik tersebut tidak bersifat lestari untuk semua isolat HIV-2.

Antigen rekombinan yang akan diekspresikan oleh plasmid pQE80Lgp125-gp36 HIV2 merupakan antigen rekombinan HIV-2 yang berbasis multiepitop. Antigen rekombinan tersebut dirancang berdasarkan studi bioinformatik 
dari protein envelope HIV-2 yang terdiri dari gp125 (surface) dan gp36 (transmembran). Sekuens asam amino yang dipilih merupakan sekuens yang bersifat immunodominan, lestari, dan dapat mengenali semua isolat HIV-2. ${ }^{9}$

Sekuens nukleotida penyandi antigen rekombinan gp125-gp36 HIV-2 selanjutnya dibuat secara sintetik dalam vektor plasmid pUC57 melalui vendor penyedia jasa dalam biologi molekuler (Macrogen). Gen sintetik tersebut kemudian dikonstruksi pada plasmid ekpresi pQE80L.

Plasmid pUC57-gp125-gp36 HIV-2 ditransformasikan pada sel E. coli Top10 kompeten. Pembuatan sel kompeten dilakukan secara kimiawi menggunakan $\mathrm{CaCl}_{2}$ yang dapat meningkatkan permeabilitas membran sel $E$. coli. $^{10}$ Dengan metode heat shock plasmid dipaksa masuk ke dalam sel karena perubahan suhu yang mendadak. Plasmid pUC57 mempunyai origin of replication pMB1 yang telah termutasi dan mampu menghasilkan 500 - 700 copy plasmid per sel. Selain itu, plasmid pUC57 mempunyai gen resisten ampisilin yang dijadikan sebagai marker seleksi transforman. ${ }^{11}$

Plasmid pQE80L digunakan sebagai plasmid pengekpresi antigen rekombinan gp125-gp36 HIV-2. Plasmid ini mempunyai promotor T5 yang dapat dikontrol dan dikenali oleh RNA polimerase E. coli dan 2 sekuens lac operator, synthetic ribosomal binding site (RBS: AAAGAGGAG) yang berperan dalam ekspresi antigen rekombinan. Pada saat tidak terdapat agen penginduksi seperti IPTG, protein lac akan menghambat promotor sehingga tidak dapat diakses oleh RNA polimerase $E$. coli. Selain itu terdapat juga fusi polyhistidine (poly-His) berupa 6xHis-tag pada ujung N-terminal yang dapat digunakan untuk purifikasi antigen rekombinan. $^{12}$

Enzim BamHI memotong pada sekuens GGATCC pada ujung 5', sedangkan untuk enzim HindIII memotong pada sekuens AAGCTT pada ujung 3' dari vektor pQE80L dan pUC57gp125-gp36. Kedua enzim tersebut menghasilkan pemotongan dengan ujung lancip (sticky end) yang dapat meningkatkan efisiensi ligasi. ${ }^{13,14}$ Pemotongan dengan dua enzim restriksi secara terpisah pada saat penyiapan DNA vektor dan DNA sisipan bertujuan untuk menghindari adanya star activity. Star activity tersebut dapat disebabkan karena konsentrasi gliserol menjadi $>5 \%(\mathrm{v} / \mathrm{v})$ akibat dari penggunaan dua enzim restriksi dalam satu reaksi. ${ }^{15}$ Purifikasi Qiaex II sebelum pemotongan enzim kedua akan membersihkan garam dan protein kontaminan yang dapat mengganggu reaksi enzimatik, sedangkan DNA akan menempel pada partikel silika. ${ }^{16}$ Pada saat pemotongan vektor pQE80L, fragmen dengan panjang $42 \mathrm{pb}$ tidak dapat divisualisasi pada gel agarose disebabkan karena ukurannya yang terlalu kecil. Kecepatan migrasi molekul DNA dalam arus listrik dipengaruhi oleh ukuran DNA tersebut. Semakin kecil ukurannya maka molekul tersebut akan bermigrasi semakin jauh. $^{17}$

Reaksi CIAP pada DNA vektor sebelum dilakukan LMA dapat mencegah terjadinya autoligasi akibat dari masih adanya vektor yang belum terpotong oleh enzim BamHI dan HindIII. Enzim alkaline phosphatase akan mendefosforilasi ujung 5' dan 3' DNA vektor. ${ }^{18}$ Ligasi DNA vektor $\mathrm{pQE} 80 \mathrm{~L}$ dan DNA sisipan gp125gp36 HIV-2 terjadi karena pembentukan ikatan phosphodiester dan ikatan hidrogen pada ujung sticky end yang saling berkomplemen. ${ }^{13}$ Perbandingan jumlah koloni antara plasmid rekombinan pQE80L-gp125-gp36 HIV-2 (5450 pb) dan kontrol ligasi yang ditransformasikan ke $E$. coli Top10 adalah 1 : 16. Adanya koloni pada kontrol ligasi kemungkinan terjadi karena adanya autoligasi dari vektor dan adanya plasmid yang belum terpotong.

Berdasarkan tiga metode verifikasi yang dilakukan, sekuens DNA penyandi 
antigen rekombinan gp125-gp36 HIV-2 berhasil dikonstruksikan pada vektor plasmid pQE80L. Plasmid rekombinan tersebut dapat diekspresikan pada sel $E$. coli yang dapat digunakan untuk mengekspresikan protein dengan promotor RNA polymerase T5 seperti BL21. ${ }^{19}$

\section{Kesimpulan}

Plasmid pengekspresi antigen rekombinan gp125-gp36 HIV-2 telah berhasil dikonstruksi dan telah terverifikasi kebenaran sekuensnya.

\section{Saran}

Pada penelitian ini, kontrol ligasi pada saat transformasi diperoleh jumlah koloni yang cukup tinggi yaitu 73 koloni. Untuk memperoleh hasil ligasi yang lebih baik, pastikan vektor plasmid terpotong seluruhnya, hal tersebut dapat dilakukan dengan cara mengecek hasil potongan dengan elektroforesis gel agarose, dan apabila belum terpotong seluruhnya, campuran reaksi dapat dilakukan penambahan waktu inkubasi.

\section{Ucapan Terima Kasih}

Ucapan terima kasih disampaikan kepada hibah Sinas HIV PRVKP FKUIRSCM yang telah mendanai penelitian ini dari awal sampai akhir, kepada Dr. dr. Budiman Bela, Sp.MK(K) dan Dr. drh. Silvia Tri Widyaningtyas, M.Biomed yang telah membimbing dalam penelitian ini.

\section{Daftar Rujukan}

1. Visseaux B, Damond F, Matheron $\mathrm{S}$, Descamps D, Charpentier C. Hiv-2 molecular epidemiology. Infect Genet Evol. 2016;46:233-7.

2. Campbell-Yesufu OT, Gandhi RT. Update on human immunodeficiency virus (HIV)-2 infection. Clin Infect Dis. 2011;52(6):7807.

3. WHO. Global AIDS Update 2018. World Health Organization; 2019.

4. Mendoza C de, Requena S, Caballero E, Cabezas T, Peñaranda M, Amengual MJ, et al. Antiretroviral treatment of HIV-2 infection. Future Virol. 2017;12(8):461-11.

5. WHO. HIV assays report 18 . World Health Organization; 2015.

6. Malloch L, Kadivar K, Putz J, et al. Comparative evaluation of the Bio-Rad Geenius HIV-1/2 Confirmatory Assay and the Bio-Rad Multispot HIV-1/2 Rapid Test as an alternative differentiation assay for CLSI M53 algorithm-I. J Clin Virol. 2013;58(SUPPL1):85-6.

7. Tchounga BK, Inwoley A, Coffie PA, et al. Re-testing and misclassification of HIV-2 and HIV-1\&2 dually reactive patients among the HIV-2 cohort of the West African Database to evaluate AIDS collaboration. $J$ Int AIDS Soc. 2014;17(1):19064.

8. Leligdowicz A, Yindom LM, Onyango C, Sarge-Njie R, Alabi A, Cotten M, et al. Robust Gag-specific $\mathrm{T}$ cell responses characterize viremia control in HIV-2 infection. $\mathrm{J} \quad \mathrm{Clin}$ Invest. 2007;117(10):3067-7.

9. Fathurrohim. Struktur dan ekspresi antigen rekombinan gp125-gp36 HIV-2 untuk deteksi antibodi antivirus HIV-2 [thesis]. Jakarta: Universitas Indonesia; 2019.

10. Hans S, Gimpel M, Glauche F, Neubauer P, Cruz-Bournazou M. Automated Cell Treatment for Competence and Transformation of Escherichia coli in a High-Throughput Quasi-Turbidostat Using Microtiter Plates. MDPI. 2018;6(60):1-14.

11. Rosano GL, Ceccarelli EA. Recombinant protein expression in Escherichia coli: advances and challenges. Front Microbiol. 2014;5:1-17.

12. Qiagen. The QIA expressionist: A handbook for high-level expression and purification of $6 \mathrm{xHis}$-tagged proteins. 5th ed. UDA: Qiagen; 2003.

13. Murray R, Granner D, Mayes P, Rodwell V. Harper' s Illustrated Biochemistry. 25th ed. United States of America: McGraw-Hill Companies; 2003.

14. Jia B, Jeon CO. High-throughput recombinant protein expression in Escherichia coli: current status and future perspectives. Open Biol. 2016;6:1-17.

15. Bitinaite J, Schildkraut I. Self-generated DNA termini relax the specificity of SgrAI restriction endonuclease. Proc Natl Acad Sci U S A. 2002;99(3):1164-6.

16. Qiagen. QIAEXII handbook for DNA extraction from agarose and polyacrilamide gels and for desalting and concentrating DNA from solutions. Qiagen; 2015.

17. Sambrook J, Russel DW. Molecular cloning: A laboratory manual. 1 st-3rd ed. 
New York: Cold Spring Harbor Laboratory Press; 2001.

18. Glick BR, Pasternak JJ. Molecular biotechnology principles and aplications of recombinant DNA. Washinton DC: ASM Pres. 2003.

19. Hayat S, Farahani N, Golichenari B, Sahebkar A. Recombinant Protein Expression in Escherichia coli (E. coli): What We Need to Know. Curr Pharm Des. 2018;24:1-8. 